\title{
Prevalence of Rheumatic Heart Disease in Puerto Rican School Children
}

\author{
MICHAEL M. SHEFFERMAN, M.D., JAY S. GOODMAN, M.D., and RAMÓN A. AIXALA, M.D.
}

$\mathrm{U}^{2}$ NTIL recently, it was believed that rheumatic fever was extremely rare, or absent, in tropical climates such as that of Puerto Rico (1-3), and it was even suggested that children with rheumatic fever be sent to Puerto Rico to recover and to avoid further attacks (4). Textbooks still much in use today stress the rarity of rheumatic fever and rheumatic heart disease in the tropics $(5,6)$. On the other hand, a few workers in Puerto Rico thought they had evidence that rheumatic heart disease was not only present but occurred frequently, representing 17 to 32 percent of all cardiac patients seen there $(7,8)$.

More recently, a study of 3,600 consecutive autopsies from 1958 to 1961 in native-born, indigent Puerto Ricans revealed that 8.4 percent of the deaths due to cardiovascular disease were the result of rheumatic heart disease (9). Furthermore, García-Palmieri and co-workers (10) reported 300 cases of acute rheumatic fever and rheumatic heart disease in patients aged 13 and over admitted to one charity hospital in San Juan, P.R., over an 8-year period and concluded that climatologic conditions are not a significant factor in the pathogenesis of this disease since it is present with "such a frequency" in this tropical area.

At the time of this study all the authors were with the heart disease control program, Department of Health of Puerto Rico, San Juan. Dr. Aixalá was director of the program. Dr. Shefferman is now assistant resident in medicine, George Washington University Hospital in Washington, D.C., and Dr. Goodman is assistant resident in medicine, Vanderbilt University Hospital in Nashville, Tenn.
Although rheumatic fever and rheumatic heart disease are known to exist in tropical areas such as Puerto Rico, prevalence or incidence data have been unavailable, particularly as compared with other geographic areas. Therefore, a study was undertaken from October 1963 through May 1964 among school children in San Juan to obtain some information on prevalence of rheumatic heart disease.

\section{Materials and Methods}

A total of 651 apparently healthy sixth-grade students (including absentees) at four representative public schools in the San Juan district were screened for cardiac murmurs. All the children examined were born in Puerto Rico except seven who were born in the continental United States. Sixteen were born in Puerto Rico but lived in the United States for periods of 4 months to 10 years. The screenees consisted of 341 boys and 310 girls aged 10 to 16 years. The average age was 12.1 years.

The children were selected, with the assistance of the department of public instruction, from the four largest schools thought by the department to be representative of the entire San Juan school district. Every sixth-grade student in the four schools was examined and included in the study.

Each child was examined by at least two physicians working independently. The examining team consisted of one cardiologist and two heart disease control medical officers with special interest in cardiology. A typical physical examination of the heart was performed on each child. Murmurs were recorded as to timing, location, intensity (grades 1 to 6 ), charac- 
ter, radiation, and change with position or respiration.

Grade 1 and grade 2, short, early systolic murmurs that tended to disappear in deep inspiration and with slowing of the pulse rate as the child relaxed were considered to be functional without further examination $(11,12)$.

In all cases, at least two of the examining physicians had to agree on the absence of organic heart disease. In cases where at least one examiner thought that organic heart disease might be present, the child was referred to the appropriate heart disease control program cardiac center for evaluation, including reexamination by a different cardiologist, electrocardiography, radiology, phonocardiography, and other examination deemed advisable by the attending cardiologist.

\section{Results}

Of the 651 school children examined, 5 gave histories of having had rheumatic fever, but none of the 5 had significant cardiac findings. No documentary evidence of prior acute rheumatic fever was available for any of the five children. Functional murmurs were heard in 281 , or 43.2 percent, of all the children examined-slightly more frequently in the girls, 46 percent, than in the boys, 39.5 percent (table 1).

Eight children, born and reared in Puerto Rico, were referred to the cardiology center for complete workup and evaluation. Of these, six were diagnosed as having no heart disease, one was suspected of having congenital heart disease, and one was diagnosed as having rheu- matic heart disease. One case of rheumatic heart disease among 651 sixth-grade Puerto Rican school children living in San Juan is an approximate prevalence of 1.5 per 1,000 for the group.

\section{Discussion}

As García-Palmieri pointed out (9), reliable studies for comparing the relative incidence and prevalence of rheumatic fever and rheumatic heart disease in different areas of the world have been few, largely because of lack of reporting of the disease and difficulties in standardized diagnosis. One apparently reliable method of carrying out an extensive comparative prevalence study in rheumatic fever has been reported (13) but was limited to the continental United States.

Because of the difficulty of obtaining reliable prevalence data, the answer to the question of how much rheumatic fever exists in a tropical area such as Puerto Rico has always depended on data such as that from private cardiological practices, autopsy studies, and hospital admissions in the area. None of these has provided prevalence data, however, and most represent personal opinions or figures based on questionable population bases.

Our findings (14) and those of GarcíaPalmieri $(9,10)$ show that when acute rheumatic fever and rheumatic heart disease occur in Puerto Rico, the clinical picture is identical with that seen in most temperate areas. This does not imply, however, that the prevalence or incidence of the disease in Puerto Rico is necessarily the same as that of the other areas.

Table 1. Results of examinations of 651 Puerto Rican school children for prevalence of rheumatic heart disease, ${ }^{1}$ by diagnosis, San Juan, P.R., October 1963-May 1964

\begin{tabular}{|c|c|c|c|c|c|c|c|}
\hline \multirow{2}{*}{ Group } & \multirow{2}{*}{ Total } & \multicolumn{2}{|c|}{ No murmurs } & \multicolumn{2}{|c|}{ Functional murmers } & \multirow{2}{*}{$\begin{array}{l}\text { Rheumatic } \\
\text { heart } \\
\text { disease }\end{array}$} & \multirow{2}{*}{$\begin{array}{l}\text { Congenital } \\
\text { heart } \\
\text { disease }\end{array}$} \\
\hline & & Number & Percent & Number & Percent & & \\
\hline $\begin{array}{l}\text { Boys } \\
\text { Girls }\end{array}$ & $\begin{array}{l}341 \\
310\end{array}$ & $\begin{array}{ll}2 & 202 \\
3 & 166\end{array}$ & $\begin{array}{l}59 \\
54\end{array}$ & $\begin{array}{l}137 \\
144\end{array}$ & $\begin{array}{l}40 \\
46\end{array}$ & $\begin{array}{l}1 \\
0\end{array}$ & $\begin{array}{l}1 \\
0\end{array}$ \\
\hline Total & 651 & 368 & 56 & 281 & 43 & 1 & 1 \\
\hline
\end{tabular}

1 Prevalence of rheumatic heart disease, 1.5 per 1,000 .

23 had a history of rheumatic fever without evidence of heart disease.

32 had a history of rheumatic fever without evidence of heart disease. 
Table 2. Surveys of school children for prevalence of rheumatic heart disease, by selected areas

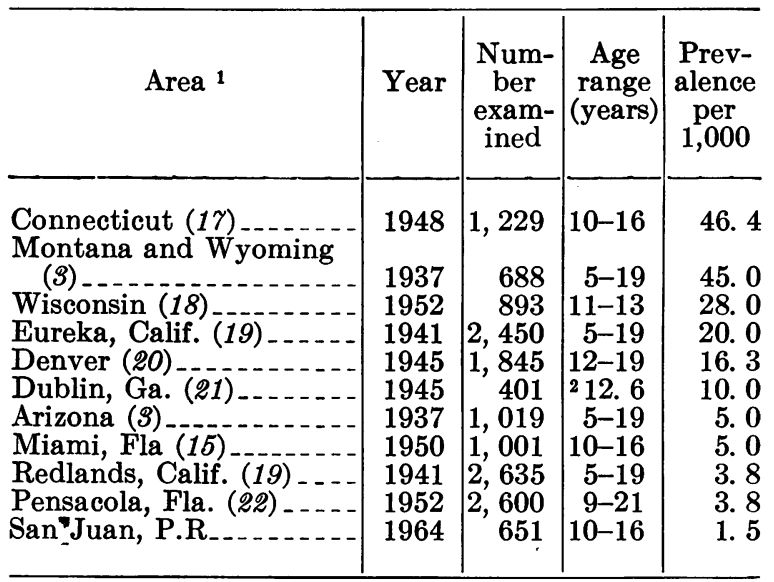

1 Numbers in parentheses indicate references.

2 Average age (range not given).

Saslaw and co-workers (15) studied 1,001 native-born school children in subtropical Dade County, Fla., for the presence of rheumatic heart disease and found a prevalence of only 5.0 per 1,000 children. In a later review of the literature, Saslaw and Streitfeld (16) graphically demonstrated an almost direct relationship of latitude to prevalence of rheumatic heart disease. This ranged from 45.0 per 1,000 at $45^{\circ}$ north latitude (Wyoming) and 16.3 per 1,000 at $40^{\circ}$ north latitude (Denver) to 5.0 per 1,000 at $25^{\circ}$ north latitude (Dade County, Fla.). A recent nationwide study of college freshmen (13) revealed a similar trend. Following Saslaw's thesis, Puerto Rico (18 ${ }^{\circ}$ north latitude) should have even less rheumatic heart disease than Miami (Dade County, Fla.). This conclusion is supported by the prevalence of 1.5 per 1,000 sixth-grade Puerto Rican school children, as presented here.

A comparison of the results of our study with those of similar studies (table 2) reveals that the prevalence of rheumatic heart disease in our study group is the lowest of all the compared areas. Puerto Rico is in the group with a prevalence of 5 per 1,000 or less, which consists of the most southern and warmest of the areas.

It should be pointed out that our data are compared with data obtained at least 12 or more years previously, although the study methods and criteria are comparable. Such comparisons are hazardous when dealing with rheumatic fever since it has been shown that incidence of the disease in some areas has decreased over the past decade (23). It would probably be of more interest to compare our present data with comparative data for Puerto Rico of 10 or 20 years previously, rather than with previous data from other areas. However, no prior prevalence information for Puerto Rico is available.

Furthermore, we wish to emphasize that the size of the study group was small, and the resulting prevalence figure, therefore, may be only an approximation of the true prevalence. However, it indicates a trend and represents the best evidence available that the prevalence of rheumatic heart disease in tropical Puerto Rico is probably lower than that of more temperate areas and may be lower than that of any area of the continental United States.

\section{Summary}

In October 1963 a study was undertaken in San Juan, P.R., to determine the prevalence of rheumatic heart disease among 651 apparently healthy sixth-grade Puerto Rican school children. They were examined for evidence of clinical cardiac abnormalities.

The prevalence of rheumatic heart disease in this group was 1.5 per 1,000 , indicating that although the sample was small the prevalence of rheumatic heart disease in Puerto Rico is probably lower than that of similar groups of children living in more temperate areas of the United States. This represents the first prevalence data available for rheumatic heart disease in Puerto Rico.

\section{REFERENCES}

(1) Holbrook, W. P.: The Army Air Force's rheumatic fever control program. JAMA 126: 84 (1944).

(2) Nichol, E. S.: Geographic distribution of rheumatic fever and rheumatic heart disease in the United States. J Lab Clin Med 21 : 588 (1936).

(3) Paul, J. R., and Dixon, G. L.: Climate and rheumatic heart disease. JAMA 108: 2096 (1937).

(4) Coburn, A. F.: The factor of infection in the rheumatic state. Williams \& Wilkins Company, Baltimore, 1931. 
(5) Friedberg, C. K.: Diseases of the heart. Ed. 2. W. B. Saunders Company, Philadelphia, 1956.

(6) Massey, F. C.: Clinical cardiology. Williams \& Wilkins Company, Baltimore, 1953.

(y) Francisco, R.: Rheumatic heart disease in the tropics with special reference to its incidence in Puerto Rico. Clinics 5: 971 (1946).

(8) Suarez, R. M.: The incidence of heart disease in Puerto Rico. Amer Heart J 29 : 339 (1945).

(9) Garcia-Palmieri, M. R.: Rheumatic fever and rheumatic heart disease as seen in the tropics. Amer Heart J 64: 577 (1962).

(10) García-Palmieri, M. R., Costas, R., and Diaz Rivera, R. S.: Rheumatic fever in the tropics. Amer Heart J 63: 18 (1962).

(11) Freeman, A. R., and Levine, S. A.: The clinical significance of the systolic murmer. Ann Int Med 6: 1371 (1933).

(12) Levine, S. A.: The systolic murmur: Its clinical significance. JAMA 101: 436 (1933).

(13) Marienfeld, C. J., Robins, M., Sandidge, R. P., and Findlan, C.: Rheumatic fever and rheumatic heart disease among U.S. college freshmen, 1956-60. Public Health Rep 79: 789 (1964).

(14) Shefferman, M. M., Goodman, J. S., Ultan, L. B., and Valdes, J.: Acute rheumatic fever in Puerto Rico. Amer J Dis Child 110:239 (1965).

(15) Saslaw, M. S., Ross, B. D., and Dobrin, M.: The incidence of rheumatic heart disease in native school children of Dade County, Florida. Amer Heart J 40 : 760 (1950).
(16) Saslaw, M. S., and Streitfeld, M. M.: Group A beta hemolytic streptococci in relation to rheumatic fever. Amer J Dis Child 92 : 550 (1956).

(17) Quinn, R. W., Liao, S. J., and Quinn, J. P.: An environmental and sociological study of rheumatic heart disease in school children from four Connecticut communities. Amer J Public Health 40: 1285 (1950).

(18) Quinn, R. W., and Kiniard, C. K.: Rheumatic (valvular) heart disease in Madison, Wis.: A survey of 7 th grade school children. Amer J Med Sci 223 : 487 (1952).

(19) Sampson, J. J., Hahman, P. T., Halverson, W. L., and Shearer, M. C.: Incidence of heart disease and rheumatic fever in school children in three climatically different California communities. Amer Heart J 29 : 178 (1945).

(20) Wedum, B. G., Wedum, A. G., and Beaghler, A. L. : Prevalence of rheumatic heart disease in Denver school children. Amer J Public Health 35: 1271 (1945).

(21) Quinn, R. W.: Incidence of rheumatic fever and heart disease in school children in Dublin, Georgia, with some epidemiological and sociological observations. Amer Heart J 32: 234 (1946).

(22) Packard, J. M., Graettinger, J. S., and Graybriel, A.: Incidence of heart disease in school children of Pensacola, Florida. J Florida Med Assoc 39 : 30 (1952).

(23) Stamler, J. A.: Cardiovascular diseases in the United States. Amer J Cardiol 10 : 319 (1962).

\section{Education Notes}

Epidemiology for Nurses. The training branch of the Communicable Disease Center, Public Health Service, will offer a course in applied epidemiology for nurses. This 5-day course, to be held June 6-10, 1966, in Atlanta, Ga., is designed for nurses who supervise or teach.

Although certain disease entities will be discussed, the purpose of the course is to strengthen the understanding of epidemiology. The curriculum includes review of epidemiologic concepts and methods, use and interpretation of statistics, illustrations of application of epidemiology to selected communicable or noninfectious diseases, and use of recently developed teaching aids. Maximum student participation in discussions and problem solving is emphasized.
For information and application forms write: Chief, Training Branch, Communicable Disease Center, U.S. Public Health Service, Atlanta, Ga. 30333.

Planning Medical Care Services and Facilities. The University of Michigan School of Public Health will hold a 2-week institute on areawide planning of medical care services and facilities. The program, starting June 13, 1966, is directed to personnel from hospital planning councils and health and welfare councils.

A Public Health Service grant has provided several traineeships for the $\$ 250$ tuition and estimated living costs of $\$ 12$ per day. Travel expenses must be paid by all participants. Additional information is available from the Director of Continuing Education, School of Public Health, University of Michigan, Ann Arbor 48104. 


\section{Program Notes}

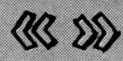

\section{Water Pollution Legislation}

Provisions of New York State's pure waters law, effective September 1, 1965, empower the State Health Commissioner to determine not only that water is being polluted but also to determine the financial ability of the polluter to correct the condition.

The law provides for making stoppollution orders effective immediately. It denies violators the right to obtain an injunction of a stop-pollution order on the ground that an application is pending to reclassify the water. The law also reduces the time allowed for appeals from 4 months to 60 days.

\section{Family Planning Clinics in Kansas}

The Kansas Legislature recently passed a law which authorizes the State board of health to establish family planning clinics in conjunction with local health departments and to cooperate with local and State departments of social welfare in an educational program.

The law allows communities interrested in establishing family planning in their local health departments to receive grant-in-aid money from the State health department. The legislation and State board of health policy permit any person 18 years old who is married or has been referred by a licensed physician to request and receive family planning information and services from the clinics in line with his personal and religious beliefs.

\section{First for Oregon Laboratory}

A case of maple syrup urine disease (MSUD) detected in March 1965 in a newborn infant in an Oregon hospital is the first known case found through a screening program. Evidence of this rare and usually fatal disease was discovered at the Oregon State Board of Health's laboratory when a sample of the infant's blood was tested by the technique Dr. Robert Guthrie (Children's
Hospital, Buffalo, N.Y.) developed to detect phenylketonuria, MSUD, and galactosemia.

The discovery, resulting from a statewide 70-hospital screening program, was the first in 8,000 tests in Oregon.

The baby with MSUD was put on a special diet from which amino acids that would cause brain damage were eliminated.-Oregon Health Bulletin, April 1965.

\section{Illinois Drops Kahn Syphilis Test}

The Illinois Department of Public Health has discontinued the Kahn test for syphilis in all its laboratories because of increasing difficulty in obtaining a satisfactory Kahn antigen source. Routine serologic tests will consist of the Venereal Disease Research Laboratory (Communicable Disease Center, Public Health Service) procedures only, except in the Chicago Branch Laboratory, where the unheated serum reagin (USR) method will continue to be used as a screening procedure.

\section{Illinois Child Abuse Law}

The Illinois legislature passed a law in April 1965 requiring hospitals and physicians to report cases of suspected child abuse immediately to the State department of children and family services.

Drafted by a committee of the Illinois Commission on Children, the law strengthens the partnership between the department of children and family services and law enforcement agencies. It enables parents to receive help in gaining the stability they need to carry out their parental responsibilities.

\section{Language Rehabilitation in Stroke}

The Indiana University's speech and hearing clinic at Bloomington is developing a demonstration program to provide language rehabilitation for stroke patients under an Indiana State Board of Health grant.
Speech pathologists will provide direct services for aphasia victims. They will plan with the patient's attending physician and program personnel, administer language examinations, and generally expedite the program.

As soon as the patient's health permits, language testing will be initiated. The training program will require cooperation of the patient's family and hospital personnel in line with the design worked out with the physician.

\section{Air Pollution Information Center}

The New York City Council of Action for Clean Air Committee is forming the nation's first information and training center devoted entirely to the problem of air pollution.

The center will help pool the resources of the many private and public agencies working for cleaner air in Metropolitan New York for the use of researchers, engineers, program administrators, and the public. It will raise funds, coordinate research, collect and transmit technical information, and train technical personnel and educators.

\section{Accrediting Extended-Care Facilities}

The Joint Commission on Accreditation of Hospitals has announced plans to establish an accreditation program for inpatient care institutions other than hospitals. The program would include such facilities as homes for the aged and certain nursing homes.

Two programs which approve inpatient care institutions other than hospitals are currently conducted by the American Hospital Association and the National Council for Accreditation of Nursing Homes. They would eventually be merged into a single national joint accreditation program under the joint commission.

Items for this page: Health departments, health agencies, and others are invited to share their program successes with others by contributing items for brief mention on this page. Flag them for "Program Notes" and address as indicated in masthead. 


\section{New Members Appointed}

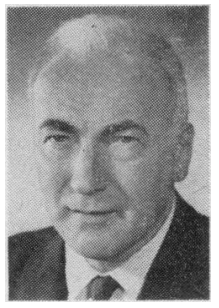

Dr. Davis

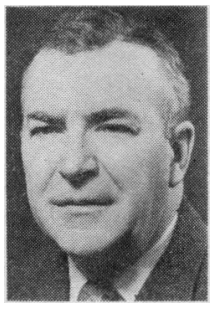

Dr. Hanlon

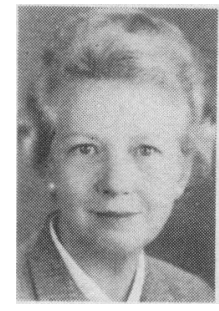

Mrs. Hansen

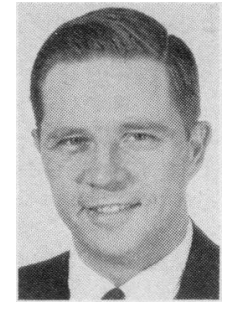

Dr. Henderson

Eight new members were appointed to the Board of Editors of Public Health Reports during 1965. They succeeded retiring members Dr. Donald T. Galagan, Mrs. Lucile P. Leone, Dr. David Littauer, Mrs. Margaret Shackelford, Dr. Leo J. Gehrig, Dr. James Hundley, Dr. Roscoe P. Kandle, and Dr. James Watt. Holdover board members include the chairman, George St.J. Perrott, and Dr. Bernard V. Dryer, Dr. F. Ellis Kelsey, and Dr. Ellis D. Sox.

Dorland J. Davis, M.D., Dr.P.H., joined the Public Health Service Commissioned Officers Corps in 1939. He has served the National Institutes of Health in several research positions since that time. After 8 years as scientific director of the National Institute of Allergy and Infectious Diseases, he was appointed director in 1964, and is now responsible for directing one of the world's largest programs of intramural, extramural, and collaborative research on these disorders.

Dr. Davis received his M.D. and his Dr.P.H. from the Johns Hopkins University. He is a fellow and member of the governing council of the American Public Health Association, and a fellow of the American Academy of Microbiology, American College of Preventive Medicine, and American Association for the Advancement of Science. He is the U.S. Representative to the Eighth International Congresses on Tropical Medicine and Malaria, and a member of the WHO Panel on Virus Diseases. He serves on the board of directors, Gorgas Memorial Institute of Tropical and Preventive Medicine, Inc., and the Scientific and Educational Council of the Allergy Foundation of America.

In 1955 Dr. Davis received the Edward Rhodes Stitt Award of the Association of Military Surgeons for outstanding research on the cause, epidemiology, and treatment of epidemic conjunctivitis. His other research interests have included hepatitis, psittacosis, and influenza.

JoHn Joseph Hanlon, M.D., M.P.H., is public health director for Detroit and Wayne County, Mich., and professor and chairman of the department of com- munity medicine at Wayne State University College of Medicine and adjunct professor of public health administration at the University of Michigan School of Public Health.

Dr. Hanlon holds bachelor and master degrees in science from the Massachusetts Institute of Technology. He received his M.D. from Wayne University in 1941 and his M.P.H. from Johns Hopkins University in 1942. He is a diplomate of the American Board of Preventive Medicine and Public Health.

Dr. Hanlon's work in public health began in 1934 in Eaton County, Mich., where he served as assistant sanitary engineer. He has held positions in the Tennessee Department of Health and the Detroit and Wayne County Department of Public Health. He served as chief of the Health Mission at the Institute of Inter-American Affairs in Bolivia from 1949 to 1951. He was medical director of the Public Health Service and chief of Public Health Division, U.S. Foreign Aid Program for the State Department from 1952 to 1957. He served as director of community health services for Philadelphia from April 1957 to September 1964. He also was professor and chairman of the department of preventive medicine and public health at Temple University School of Medicine and has lectured at various schools of public health and schools of medicine in the United States and abroad.

Dr. Hanlon holds membership in various national, international, State, and local professional organizations. He is a fellow of the American Public Health Association, American College of Preventive Medicine and Public Health, and a member of the Association of 


\section{To PHR Board of Editors}

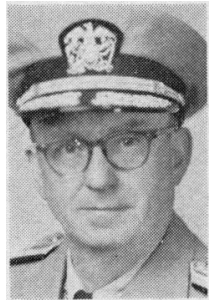

Dr. Lloyd

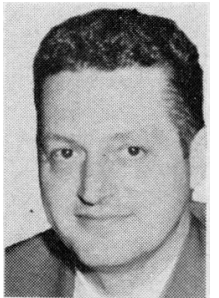

Dr. Offutt

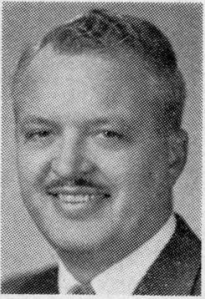

Dr. Smith

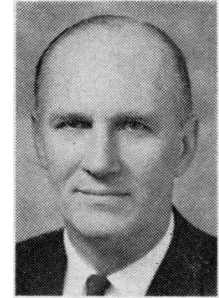

Mr. Stevenson
Professors of Preventive Medicine. He is a member of the World Health Organization Expert Panel on Public Health Administration and a consultant to the Pan American Health Organization.

ANN C. Hansen, M.P.H., is engaged in public health nursing research at the University of North Carolina School of Public Health in Chapel Hill, where she is associate professor of public health nursing. She joined the faculty of the School of Public Health in 1958 following a year as research associate in the department of sociology and anthropology at Cornell University. Her public health nursing experience includes work with State and local agencies, the maternal and child health division of the Johns Hopkins University School of Hygiene and Public Health, and the home care program of the University of North Carolina School of Medicine.

Mrs. Hansen is a graduate of Stuart Circle Hospital School of Nursing, Richmond, Va. She earned a bachelor of science degree from the Johns Hopkins University and a master of public health degree from the North Carolina University School of Public Health.

Mrs. Hansen is a fellow of the American Public Health Association and a member of the American Nurses' Association and the National League for Nursing. She is author and co-author of many articles in professional journals.

Donald A. Henderson, M.D., M.P.H., is chief of the Smallpox Eradication Program, Communicable Disease Center, Public Health Service in Atlanta, Ga.

Dr. Henderson was graduated from Oberlin College in 1950. He received his medical degree from the University of Rochester School of Medicine in 1954 and the master of public health degree from the Johns Hopkins University School of Hygiene and Public Health in 1960. He served his internship and residency in medicine and pathology at the Mary Imogene Bassett Hospital in Cooperstown, N.Y.

He served as assistant chief of the Epidemiology Branch and chief of the Epidemic Intelligence Service for two periods, 1956-57 and 1960-61. He is assistant professor of preventive medicine and comnunity health at Emory University School of Medicine in Atlanta.

Dr. Henderson is a fellow of the American Public Health Association and a member of the American Board of Preventive Medicine and several other professional associations. He has served on the Surgeon General's Advisory Committees on Influenza, Measles Vaccines, and Immunization Practices. He is technical consultant to the World Health Organization Special Committee on Measles Vaccines and a member of the WHO Scientific Group on Human Virus Vaccines.

In 1954 Dr. Henderson received the Corner Award in the History of Medicine from the University of Rochester and, in 1962, the Public Health Service Commendation Medal.

RALPH S. LLoYd, D.D.S., retired February 1, 1966, as Assistant Surgeon General and Chief Dental Officer of the Public Health Service, a post he held since 1962.

He received his bachelor of science and his doctoral degrees from Western Reserve University Dental School in 1932. He did postgraduate study in maxillofacial prosthesis at the Memorial Hospital in New York City and at the Mayo Clinic in Rochester, Minn.

After serving his internship at the U.S. Marine Hospital in Baltimore, Md., Dr. Lloyd was appointed assistant dental surgeon. He served at the Public Health Service Outpatient Clinic in Washington, D.C., and as chief dental officer at the U.S. Marine Hospital in Savannah, Ga.

Dr. Lloyd saw active duty during World War II with the United States Coast Guard where he was dental surgeon aboard the USS Callaway in the Pacific Theater. In 1944 he returned to the PHS Hospital (formerly the U.S. Marine Hospital) in Baltimore as assistant chief and later chief dental officer. In 1952 he was appointed dental director of the National Institutes of Health Clinical Center in Bethesda, Md.

Dr. Lloyd is a member of various professional organizations. He has written articles on many aspects of dental health and dental problems for leading professional journals. 
A. C. Offutr, M.D., is Indiana State Health Commissioner. Dr. Offutt is a graduate of Franklin College, Franklin, Ind., and Indiana University School of Medicine. After completing his medical education he entered the Regular Army. Following service with a medical battalion he graduated from the Medical Field Service School in Carlisle, Pa., and the Command and General Staff School at Fort Leavenworth, Kans. He was an instructor at the field service school prior to duty in the European Theater of Operations during World War II.

In 1951 he joined the staff of the Indiana State Board of Health as director of communicable disease control. He subsequently served as director of tuberculosis control and as director of preventive medicine for the State board of health.

In 1954 Dr. Offutt was appointed State health commissioner. He is presently an assistant professor of public health of Indiana University School of Medicine.

He is past president of the Middle States Branch, American Public Health Association, and of the Association of State and Territorial Health Officers.

Robert Leslie SMITH, M.D., M.P.H., is regional health director of Public Health Service Region IX, San Francisco. He was staff director for the White House Conference on Health from September to November 1965.

Dr. Smith received his bachelor's degree from Bradley University in Peoria, Ill., his M.D. degree from the University of Illinois College of Medicine, and his master of public health degree from Tulane University. He interned at the U.S. Marine Hospital in San Francisco and was resident physician at Wisconsin State Tuberculosis Sanatorium. He was certified by the American Board of Preventive Medicine in 1953.

From 1947 to 1949 Dr. Smith was assistant superintendent of public health in New Orleans. He was assistant commissioner of health, Territory of Alaska in
Anchorage from 1949 to 1952 . He has also held positions with the Public Health Service Bureau of State Services and was deputy chief of the Division of Health Mobilization Services.

In 1955 Dr. Smith was appointed deputy director of the Health Office of the Federal Civil Defense Administration in Battle Creek, Mich. He also served as assistant administrator for health and medical affairs with the Federal Civil Defense Administration. He was a U.S. representative on the NATO medical committee from 1957 to 1961 .

Albert H. Stevenson, M.S., recently was appointed chief engineer of the Public Health Service. He had been chief sanitary engineer of the Division of Indian Health in Washington, D.C.

Mr. Stevenson holds a bachelor's degree in civil engineering from Union College and a master's degree in engineering from Harvard University.

He was assistant district engineer for the New York Department of Health in Syracuse in 1937 and assistant engineer for Malcolm Pirnie Consulting Engineer in New York in 1939. He was commissioned in the Public Health Service in 1942 as a staff engineer in the New York Regional Office. He acted as consultant to cities on water and sewerage projects, shellfish sanitation, and interstate carrier sanitation. He was executive assistant and later deputy officer of the Robert A. Taft Sanitary Engineering Center from 1947 to 1954.

Mr. Stevenson received the Public Health Service Meritorious Service Medal in 1963. He is a member of the American Public Health Association and the American Society of Civil Engineers.

He is the author of "The U.S. Public Health Service's Sanitary Facility Construction Program for American Indians and Alaska Natives" and of papers on studies on the relationship between natural bathing water quality and health, shellfish sanitation, water quality, and public health aspects of civil defense.

\section{Training Programs in X-Ray Sciences}

The Public Health Service's Division of Radiological Health has signed a $\$ 290,000$ contract with Oregon State University for the development and operation of training programs in X-ray sciences which can be incorporated into the university's established curriculum.

The university also will develop a unit to carry out research, evaluation, and development projects in X-ray science and engineering to include evaluation of instruments used in X-ray measurement, development of a methodology for the evaluation of $\mathrm{X}$-ray protective devices and materials, and methodology and instrumentation for the measurement of $\mathrm{X}$-radiation.

The Service expects the projects developed at the university to serve as models for similar programs at other institutions. 


\section{Conference Calendar}

April 1-\%, 1966: American Academy of General Practice, Boston, Mass.

April 4-5, 1966: American Medical Association's Third Congress on Environmental Health Problems, Drake Hotel, Chicago, Ill. Information: EHC, Department of Environmental Health, American Medical Association, 535 North Dearborn Street, Chicago, Ill.

April 4-6, 1966: New York Academy of Sciences and the Public Health Service Audiovisual Facility (cosponsors) Conference on "Biomedical Communication: Problems and Resources," Waldorf-Astoria Hotel, New York, N.Y. Information: Dr. James Lieberman, Director, Public Health Service Audiovisual Facility, Communicable Disease Center, Atlanta, Ga., 30333.

April 6-8, 1966: Southern Water Resources and Pollution Control Conference (Southern Municipal and Industrial Waste Conference), North Carolina State University, Raleigh, N.C. April 12-16, 1966: Federation of American Societies for Experimental Biology, Atlantic City, N.J.

April 13-16, 1966: American Orthopsychiatric Association, San Francisco, Calif.

April 15-17, 1966: American Society of Internal Medicine, New York, N.Y.

A pril 18-22, 1966: American College of Physicians, New York, N.Y.

April 24-28, 1966: International Congress of Infectious Diseases and the International Society for the Study of Infectious and Parasitic Diseases, Munich, Germany.

April 25-2\%, 1966: American Academy of Pediatrics (spring meeting), Montreal, Ontario, Canada.

April 25-28, 1966: American Industrial Health Conference (annual convention of the Industrial Medical Association and the American Association of Industrial Nurses), Sheraton Cadillac Hotel, Detroit, Mich. Information: American Industrial Health Conference, 55 East Washington Street, Chicago, Ill. 60602.
April 25-29, 1966: American Federation of Information Processing Societies and Joint Computer Conference, Boston, Mass.

May 1-5, 1966: American Society for Microbiology (annual meeting), Los Angeles, Calif. May 3-21, 1966: World Health Assembly, Geneva, Switzerland.

May 9-13, 1966: American Psychiatric Association, Atlantic City, N.J.

May 10-14, 1966: American Association on Mental Deficiency, Chicago, Ill.

May 11, 1966: American Cancer Society (scientific meeting), San Francisco, Calif.

May 15-17, 1966: American Society for Personnel Administration, Miami Beach, Fla.

May 16-20, 1966: American Industrial Hygiene Association, Pittsburgh, $\mathrm{Pa}$.

May 22-25, 1966: National Conference of Tuberculosis Workers, National Tuberculosis Association, and American Thoracic Society (joint meeting), San Francisco, Calif.

June 5-8, 1966: International Congress on Smoking and Health, New York, N.Y.

June 12-16, 1966: Annual Educational Conference of the National Association of Sanitarians, Chicago, Ill.

June 13-17, 1966: American Nurses Association, San Francisco, Calif.

June 13-18, 1966: American Society for the Advancement of Science, Seattle, Wash.

June 20-24, 1966: Air Pollution Control Association, San Francisco, Calif.

June 21-24, 1966: International Data Processing Conference-Business Exposition, Chicago, Ill.

June 26-30, 1966: American Medical Association (annual meeting), Chicago, Ill.

June 26-30, 1966: American Veterinary Medical Association, Louisville, $\mathrm{Ky}$.

Announcements for publication should be forwarded to Public Health Reports 6 months in advance of meeting. 
PARRISH, HENRY M. (University of Missouri School of Medicine): Incidence of treated snakebites in the United States. Public Health Reports, Vol. 81, March 1966, pp. 269-276.

The incidence of treated poisonous snakebites in the United States (excluding Alaska and Hawaii) was determined by using hospital records, physician reports, and death certificates. An estimated 6,680 persons were treated for poisonous snakebites during 1959 , an incidence of 3.74 bites per 100,000 population. The case-fatality rate was 0.21 percent. Males had higher bite rates than females, and nonwhites had higher

rates than whites. Fifty-two percent of the bites happened to persons less than 20 years of age. Regions having the highest bite rates per 100,000 population were the West South Central, South Atlantic, and East South Central. July and August were the peak months for snakebite accidents. Most of the bites were inflicted on the victims' extremities-38 percent on the upper extremities and 58 percent on the lower.

\section{HESS, CATHERINE B. (Public Health Service): New trends in narcotic addiction control. Public Health Reports, Vol. 81, March 1966, pp. 277-281.}

Drug addiction has proved most unresponsive to traditional therapy. Contributing to the low cure rate are the complexities related to the pharmacological and physiological properties of addictive drugs, the personality and attitudes of the addict, the environmental influences at work on him, and the ritual involved in obtaining and using drugs. Treatment approaches have ranged from the extremes of civil commitment for all addicts in California to the supplying of narcotic drugs to addicts in England. The British approach of supplying drugs, including heroin, has not been as successful as early reports indicated. Heroin use necessitates injections every 4 to 6 hours, and the addict develops increasing tolerance to it ; moreover he cannot work while using heroin.

There are drugs, however, that can be used in maintenance programs which permit the addict to function normally on one oral dose per day. Programs using either cyclazocine or methadone are functioning in Vancouver and Toronto, Canada, and in Lexington, Ky., and New York City. Supplying one of these medications would probably eliminate the need to steal and rob to support the addiction habit.

New approaches to treatment must include halfway houses, day-care centers, vocational training, and job placement. In addition, new techniques of group therapy may be practiced in living situations such as those afforded by the Synanon Houses in California and Daytop Lodge in New York. Even with these new approaches, however, the cure rate remains around 5 percent. Best results seem to be attained in a setting of parole and probation. Under parole and probation supervision, 27 percent of 695 subjects remained drug free and without violations according to a recent New York State investigation.

KOWALSKI, XAVIER (Monsanto Company), and HILTON, THOMAS B.: Comparison of chlorinated cyanurates with other chlorine disinfectants. In swimming pool operation. Public Health Reports, Vol. 81, March 1966, pp. 282-288.

Data collected from the practical operation of swimming pools in St. Louis County, Mo., in 1960 and 1963 were evaluated statistically to compare the disinfecting ability of the chlorinated cyanurates with other sources of chlorine. The results from each period had to be evaluated separately since the number of controlled variables was different in $\mathbf{1 9 6 0}$ and 1963. Both sets of data showed that pools treated with chlorinated cyanurates had a better disinfection record than pools treated with other common chlorine sources. The good disinfection record of pools treated with the chlorinated cyanurates apparently was related to the uniform level of the chlorine residual provided by the stabilizing action of cyanuric acid. Bad housekeeping practices increased the disinfection failures. Good disinfection was obtained with any chlorine source investigated provided adequate available chlorine residual was maintained continuously in the pool.

It appears that an organized effort is advisable on the part of health department officials and industrial organizations to educate pool owners in the necessity of maintaining safe and healthful pool water by following strict housekeeping practices. Choosing the right chlorine disinfectant from among those investigated in this work may allow the operator to maintain a uniform supply of the disinfectant and thus minimize the periods of poor disinfection. The chlorinated cyanurates with cyanuric acid as a stabilizer meet the disinfectant requirements. 